ISSN : 1979-861X

e-ISSN : 2549-1555

\title{
PROFIL WIRAUSAHA KULINER DI PEKANBARU TAHUN 2020
}

\author{
Sukarni \\ Fakultas Keguruan dan Ilmu Pendidikan UIR Pekanbaru, Kampus Marpoyan KM 10 \\ Pekanbaru, 28284, Indonesia \\ Email: sukarnifkipuir@edu.uir.ac.id
}

\begin{abstract}
ABSTRAK
Penelitian ini dilaksanakan untuk menjawab permasalahan (1) Bagaimana gambaran tingkat pendidikan dan omzet penjualan wirausaha di Pekanbaru, (2) Bagaimana gambaran keuntungan dan jenis usaha wirausaha di Pekanbaru, (3) Apakah terdapat hubungan antara keuntungan dengan profil wirausaha di Pekanbaru. Sampel penelitian ini diambil 60 orang wirausaha dengan pourporsive sampling. Data dianalisa dengan statistik non parametrik. hasil penelitian ini. Mengetahui hubungan tingkat pendidikan dan omzet penjualan wirausaha di Pekanbaru. Tingkat pendidikan berkorelasi dengan omzet dan jumlah karyawan hal ini ditunjukan dengan perolehan nilai Sign < 0,05, sedangkan jenis usaha, tingkat pendidikakan tidak berkorelasi dengan laba, jenis kelamin dan lama usaha karena perolehan nilai Sign $>0,05$. Laba berkorelasi secara signifikan dengan omzet dan lama usaha, hal ini ditunjukan dengan nilai Sig yang diperoleh $<0,05$. Sedangkan laba tidak berhubungan dengan jenis usaha, tingkat pendidikan, jenis kelamin dan jumlah karyawan hal ini terlihatdari nilai Sig yang diperoleh $>0,05$. Jenis usaha berkorelasi positif dengan omzet, jenis kelamin dan jumlah karyawan hal ini terlihat dari perolehan Sig < 0,05, sedangkan jenis usaha tidak ada hubungan dengan laba, tingkat pendidikan, lamanya usaha karena nilai sig $>0,05$.
\end{abstract}

Kata kunci: kuliner, keuntungan, omzet, profil, wirausaha

\begin{abstract}
This research was conducted to answer the problem (1) How to describe the level of education and sales turnover of entrepreneurs in Pekanbaru, (2) How to describe the benefits and types of entrepreneurial business in Pekanbaru, (3) Is there a relationship between profitability and entrepreneurial profile in Pekanbaru. The sample of this study was taken 60 entrepreneurs with pourporsive sampling. Data were analyzed with nonparametric statistics. the results of this study. Knowing the relationship between education level and entrepreneurial sales turnover in Pekanbaru. The level of education correlates with turnover and the number of employees this is indicated by the acquisition value of Sign $<0.05$, while the type of business, the level of education does not correlate with earnings, gender and length of business due to the acquisition of Sign value $>$ 0.05. Profit correlates significantly with turnover and length of business, this is
\end{abstract}


indicated by the Sig value obtained $<0.05$. While profits are not related to the type of business, education level, gender and number of employees, this can be seen from the Sig value obtained $>0.05$. The type of business is positively correlated with turnover, gender and number of employees, this can be seen from the acquisition of sign $<0.05$, while the type of business has no relationship with earnings, education level, duration of business because the sign value $>0.05$.

Key words: culinary, entrepreneurship, profile, profit, turnover

\section{PENDAHULUAN}

Pekanbaru sebagai kota yang sedang tumbuh menjadi kota besar sehingga sangat diminati oleh para wirausaha terutama para wirausaha kuliner. Hal ini terlihat dari banyaknya usaha kuliner tumbuh di Pekanbaru, baik yang mempunyai modal besar seperti cofee dan resto maupun yang punya modal kecil seperti usaha kuliner dengan gerobak atau sewa tempat di depan ruko ataupun di pinggir jalan. Terlihat pada sore sampai tengah melam mereka jualan ada yang laris dan ada yang kurang laris.

Meski demikian semakin hari semakin banyak para pedagang di Kota Pekanbaru mulai dari berjualan minuman ringan ataupun makana ringan yang banya sekali macamnya seprti capucino, piscok (pisang coklat), khebab dan lain sebagainya. Minuman dan makanan ringan ini mereka hanya berjualan bermodalkan gerobak dan buka hanya sore sampai malam. Ada juga yang jualan bakso dan mie ayam atau yng sejenisnya tapi mereka punya tempat yang permanen juga ada yang jualan dengan jumlah karyawan lebih dari 3 orang.

Berdasarkan hasil observasi dan pengamatan peneliti, terlihat di pusat-pusat perbelanjaan serta di lokasi sekitaran kampus banyak wirausaha muda khususnya usaha kuliner. Setelah dilakukan wawancara terhadap beberapa orang usahawan kuliner, mereka sangat menikmati usaha mereka dan ada yang baru memulai usaha ada juga yang berjalan cukup lama yaitu diatas 10 tahun. Apakah mereka menikmati karena keuntungan yang cukup besar, apakah karena mereka usaha mereka sesuai dengan bakat atau karena terpaksa harus menikmati karena sulitnya mencari pekerjaan. Hal yang menarik untuk diteliti ialah apakah ada hubungannya kesenangan mereka berjualan dengan lokasi, dengan jenis usaha yang mereka tekuni atau dengan tingkat pendidikan mereka. Asumsinya bahwa mereka betah karena keuntungan yang mereka peroleh.

\section{METODE}

Data akan dikumpulkan dengan mengedarkan angket serta wawancara kepada respoden. Sampel penelitian ini diambil secara pourporsive sampling dengan menetapkan jumlah sampel sebanyak 45 orang. Data akan dianalisa dengan statistik non parametrik karena data yang dikumpulkan adalah data nominal dan data ordinal, sehingga untuk melihat hubunganya akan di analisis 
dengan statistik non parametrik yaitu dengan korelasi bivariate dengan bantuan SPSS.

\section{HASIL DAN PEMBAHASAN}

\subsection{Gambaran Umum Responden}

Penelitian ini dilaksanakan di Pekanbaru dengan melakukan wawancara terhadap 45 orang respoden, Dari 45 yang diwawancarai ada tiga orang tidak memberikan jawaban yang jujur menurut penilaian peneliti sehingga datanya tida ikut dianalisa. Selain itu juga ada tiga orang yang tidak mau menyebutkan modal serta omzet mereka, sehingga yang di analisa hanya 39 responden.

Dari 39 orang wirausaha yang jadi responden penelitian ini $61,5 \%$ adalah laki-laki dan 38,5\% perempuan. Berikut ini, tingkat pendidikan responden umumnya tamat SMA yaitu 51,3\% sedang yang tamat S1 ada sebanyak 33,3\% dan tamat SMP dan SD masing masing $7,7 \%$. Responden yang ditanya sangat beragam sekali, lama mereka dalam menjalankan usaha, mulai dari 1th sampai yang terlama 14 tahun. Dalam hal jumlah karyawan juga sangat beragam, mulai dari yang tidak memiliki karyawan sampai dengan jumlah karyawan 11orang.

\subsection{Deskripsi Data}

Berikut ini di tampilkan perolehan data tentang modal, omzet dan laba wirausaha serta jenis usaha.

1) Modal

Modal wirausaha di Pekanbaru umunya di bawah dari Rp. 20 juta. Hanya 10 orang yang memiliki modal diatas Rp. 20 juta yaitu, yang jenis usahanya (1) Soto, (2) Roti, (3) londri, (4) café \& resto, (5) café\&resto, (6) ikan salai, (7) foto copy, (8) makanan, (9) makanan, (10) toko obat. Untuk jelasnya dapat dilihat gambar 1 .

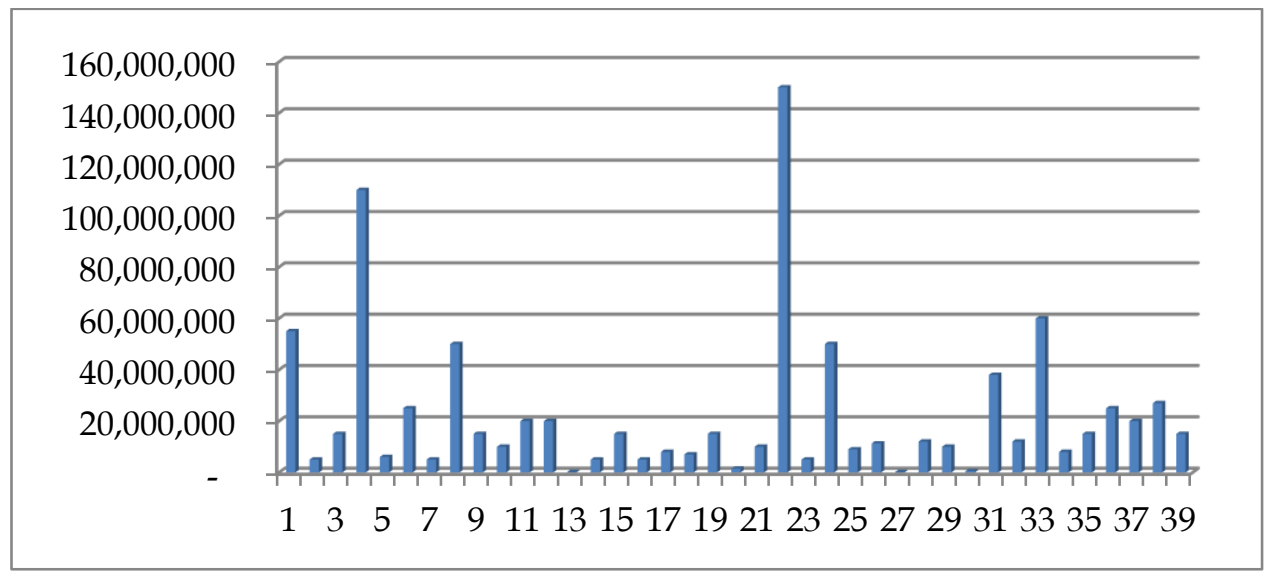

Gambar 1. Modal wirausaha Pekanbaru

2) Omzet

Omzet ini adalah jumlah penjualan setiap harinya atau periode tertentu. Wira usaha di Pekanbaru. Berikut ini adalah gambaran porsentase omzet dibandingkan dengan modal.

Ada dua jenis usaha yang mempunyai omzet cukup besar jika dibandingkan modal yaitu usaha 
Ceker bakar dan usaha katela goreng. Untuk lebih jelasnyadapat dilihat gambar 2 .

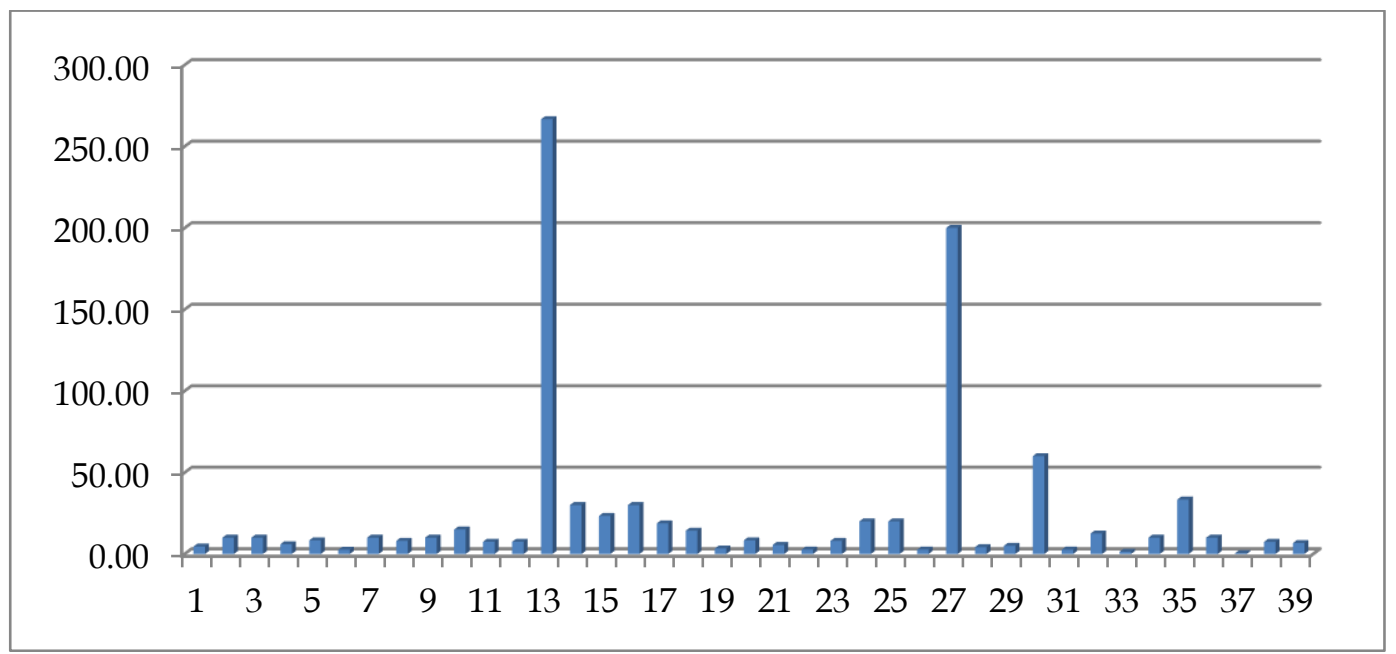

Gambar 2. Omzet Penjualan

3) Keuntungan

Gambaran keuntungan yang diperoleh rata dibawah $20 \%$ dan hanya tiga jenis usaha yang mempunyai omzet cukup besar jika dibandingkan modal yaitu usaha Ceker bakar dan usaha katela goreng. Untuk lebih jelasnya dapat dilihat gambar 3 .

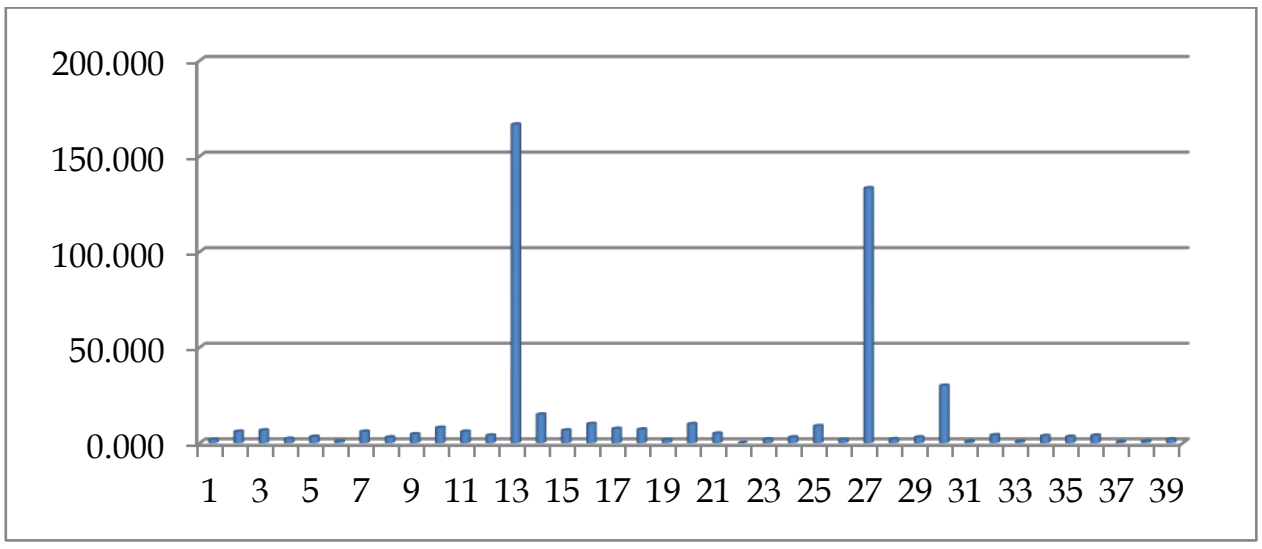

Gambar 3. Keuntungan Penjualan 


\subsection{Analisis Korelasi Non Parametrik}

Tabel 1. Korelasi

\begin{tabular}{|c|c|c|c|c|c|c|c|c|}
\hline & & $\begin{array}{c}\text { JENIS } \\
\text { USAHA }\end{array}$ & LABA & $\begin{array}{l}\mathrm{OM} \\
\mathrm{ZET}\end{array}$ & PDDK & $\begin{array}{c}\text { KELAMI } \\
\mathrm{N}\end{array}$ & LAMA & $\begin{array}{c}\text { KARYW } \\
\text { AN }\end{array}$ \\
\hline \multirow[t]{3}{*}{ JENIS USAHA } & $\begin{array}{l}\text { Correlation } \\
\text { Coefficient }\end{array}$ & 1.000 & .161 & $.335^{\star}$ & .105 & $-.343^{*}$ & .288 & $.374^{\prime}$ \\
\hline & $\begin{array}{l}\text { Sig. (2- } \\
\text { tailed) }\end{array}$ & & .328 & .037 & .527 & .033 & .076 & .019 \\
\hline & $\mathrm{N}$ & 39 & 39 & 39 & 39 & 39 & 39 & 39 \\
\hline \multirow[t]{3}{*}{ LABA } & $\begin{array}{l}\text { Correlation } \\
\text { Coefficient }\end{array}$ & .161 & 1.000 & $.765^{\star *}$ & .044 & -.014 & $.503^{* *}$ & .290 \\
\hline & $\begin{array}{l}\text { Sig. (2- } \\
\text { tailed) }\end{array}$ & .328 & & .000 & .793 & .931 & .001 & .073 \\
\hline & $\mathrm{N}$ & 39 & 39 & 39 & 39 & 39 & 39 & 39 \\
\hline \multirow[t]{3}{*}{ OMZET } & $\begin{array}{l}\text { Correlation } \\
\text { Coefficient }\end{array}$ & $.335^{*}$ & $.765^{\star *}$ & 1.000 & $.355^{*}$ & -.116 & $.528^{* *}$ & $.533^{* *}$ \\
\hline & $\begin{array}{l}\text { Sig. (2- } \\
\text { tailed) }\end{array}$ & .037 & .000 & & .026 & .483 & .001 & .000 \\
\hline & $\mathrm{N}$ & 39 & 39 & 39 & 39 & 39 & 39 & 39 \\
\hline \multirow[t]{3}{*}{ PDDK } & $\begin{array}{l}\text { Correlation } \\
\text { Coefficient }\end{array}$ & .105 & .044 & $.355^{\star}$ & 1.000 & .082 & .112 & $.344^{\prime}$ \\
\hline & $\begin{array}{l}\text { Sig. (2- } \\
\text { tailed) }\end{array}$ & .527 & .793 & .026 & & .620 & .499 & .032 \\
\hline & $\mathrm{N}$ & 39 & 39 & 39 & 39 & 39 & 39 & 39 \\
\hline \multirow[t]{3}{*}{ KELAMIN } & $\begin{array}{l}\text { Correlation } \\
\text { Coefficient }\end{array}$ & $-.343^{*}$ & -.014 & -.116 & .082 & 1.000 & -.285 & -.134 \\
\hline & $\begin{array}{l}\text { Sig. (2- } \\
\text { tailed) }\end{array}$ & .033 & .931 & .483 & .620 & & .078 & .415 \\
\hline & $\mathrm{N}$ & 39 & 39 & 39 & 39 & 39 & 39 & 39 \\
\hline \multirow[t]{3}{*}{ LAMA } & $\begin{array}{l}\text { Correlation } \\
\text { Coefficient }\end{array}$ & .288 & $.503^{* *}$ & $.528^{* *}$ & .112 & -.285 & 1.000 & $.585^{\star \star}$ \\
\hline & $\begin{array}{l}\text { Sig. (2- } \\
\text { tailed) }\end{array}$ & .076 & .001 & .001 & .499 & .078 & & .000 \\
\hline & $\mathrm{N}$ & 39 & 39 & 39 & 39 & 39 & 39 & 39 \\
\hline \multirow[t]{3}{*}{ KARYWAN } & $\begin{array}{l}\text { Correlation } \\
\text { Coefficient }\end{array}$ & $.374^{*}$ & .290 & $.533^{* *}$ & $.344^{*}$ & -.134 & $.585^{* *}$ & 1.000 \\
\hline & $\begin{array}{l}\text { Sig. (2- } \\
\text { tailed) }\end{array}$ & .019 & .073 & .000 & .032 & .415 & .000 & \\
\hline & $\mathrm{N}$ & 39 & 39 & 39 & 39 & 39 & 39 & 39 \\
\hline
\end{tabular}

Dari table print out SPSS korelasi non parametrik dapat ditafsirkan sbagai berikut:
1) Jenis usaha berkorelasi positif dengan omzet, jenis kelamin dan jumlah karyawan hal ini terlihat 
dari perolehan sign $<0,05$, sedangkan jenis usaha tidak ada hubungan dengan laba, tingkat pendidikan, lamanya usaha karena nilai sign $>0,05$.

2) Omset berkorelasi terhadap jenis usaha, laba, tingkat pendidikan, lama usaha dan jumlah karyawan berhubungan secara siknifikan ini dibuktikan dengan nilai sig $<0,05$, sedangkan nilai sig untuk jenis kelamin 0,483 artinya tidak terdapat hubungan antara omzet dengan jenis kelamin $(0,483>$ $0,05)$.

3) Laba berkorelasi secara signifikan dengan omzet dan lama usaha, hal ini ditunjukan dengan nilain Sig yang diperoleh $<0,05$. Sedangkan laba tidak berhungan dengan jenis usaha, tingkat pendidikan, jenis kelamin dan jumlah karyawan hal ini terlihat dari nilai Sig yang diperoleh > 0,05 .

4) Tingkat pendidikan berkorelasi dengan omzet dan jumlah karyawan hal ini ditunjukan dengan perolehan nilai Sign < 0,05, sedangkan jenis usaha, tingkat pendidikakan tidak berkorelasi dengan laba, jenis kelamin dan lama usaha karena perolehan nilai Sign $>0,05$.

5) Jenis kelamin tidak berkorelasi dengan omzet, laba, tingkat pendidikan, lama usaha dan jumlah karyawan karena perolehan nilai Sign > 0,05.

6) Lama usaha berkorelasi dengan dengan oset, laba dan jumlah karyawan hal ini diperlihatkan oleh perolehan nilai Sign $<0,05$. Sedangkan lama usaha tidak berkorelisi dengan tingkat pendidikan dan jenis kelamin kaena perolehan nilai Sign $>0,05$.

7) Jumlah karyawan berkorelasi dengan omzet, tingkat pendidikan dan lama usaha seperti yangdiperlihatkan oleh nilai perolehan Sign < 0,05, dan tidak berkorelasi dengan laba dan jenis kelamin karena nilai perolehan Sign $>0,05$.

Perolehan hasil penelitian menggambarkan bahwa para wira usaha di Pekanbaru umumnya berpendidikan SMA dan Perguruan Tinggi meskipun tingkat pendidikan tidak berkorelasi dengan laba yang diperoleh serta lama usaha. Meskipun tingkat pendidikan berkorelasi positif dengan omzet dan jumlah karyawan. Disini terlihat bahwa tingkat pendidikan berkorelasi dengan omzet tidak dengan laba. Jadi yang utama adalah amzet sehingga keuntungan itu akan mengikuti. Semakin tinggi tingkat pendidikan seseorang maka dia akan fokud pada omset penjualan, demikian pula terhadap jumlah karyawan. Dengan kata lain semakin tinggi tingkat pendidikanya semakin bisa seseorang me manage usahanya. Orang yang mampu memanage usaha ini ada orang yang lebih mengutamakan misi bisnisnya dari pada status (Mas`ud, 2004). selain itu juga memiliki kemampuan mengindentifikasi dan menyelesaikan persoalan sehingga tidak menghalangi mereka mencapai tujuan.

Bagaimana agar omzet tetap besar sehingga laba dengan sendirinya akan terdongkrak naik karena omzet berkorelasi dengan laba. Sebagaimana temuan penelitian yaitu 
omset berkorelasi terhadap laba, pendidikan, lama usaha dan jumlah karyawan berhubungan secara siknifikan ini dibuktikan dengan nila Sig $<0,05$, sedangkan nilai Sig untuk jenis kelamin 0,483 artinya tidak terdapat hubungan antara omzet dengan jenis kelamin $(0,483>0,05)$. Demikian pula halnyan dengan Tingkat pendidikan berkorelasi dengan omzet dan jumlah karyawan hal ini ditunjukan dengan perolehan nilai Sign $<0,05$, sedangkan tingkat pendidikakan tidak berkorelasi dengan laba, jenis kelamin dan lama usaha karena perolehan nilai Sign > 0,05 .

Selanjutnya Laba berrkorelasi secara signifikan dengan omzet dan lama usaha, hal ini ditunjukan dengan nilain Sig yang diperoleh $<0,05$. Sedangkan laba tidak berhungan dengan jenis usaha, tingkat pendidikan, jenis kelamin dan jumlah karyawan hal ini terlihatdari nilai Sig yang diperoleh $>0,05$. Sedangkan Jenis usaha berkorelasi positif dengan omzet, jenis kelamin dan jumlah karyawan hal ini terlihat dari perolehan sign $<0,05$, sedangkan jenis usaaha tidak ada hubungan dengan laba, tingkat pendidikan, lamanya usaha karena nilai sign $>0,05$.

Menurut John A. Welsh dan Jerry F. White dalam Astamoen (2008: 90), ada beberapa ciri profil wirausaha yang sukses yang dimiliki oleh wirausaha kota Pekanbaru seperti kebutuhan mendasar untuk mengendalikan dan mengarahkan. Wirausaha terkadang memang naik turun persaingan usaha dimana mana, namun percaya rezeki pasti dating dan tidak tertukar, dan tetap semangat menjalankan usaha yang sedang kita jalani. Hal yang penting dalam melakukan usaha tersebut adalah kesabaran dan juga memusatkan tenaga serta pikiran untuk terus berusaha mengembangkan usahanya, dan juga membutuhkan waktu yang lama dan tenaga yang tidak sedikit. Didalam usaha itu harus ada namanya kejujuran dan kepercayaan adalah modal awal dan paling dasar. Serta jangan takut untuk memulai usaha, karena di zaman sekarang wirausaha sangat menjanjikan bagi pelaku usaha itu sendiri, sebelum memulai usaha perhatikan apa yang akan banyak di gemari oleh orang banyak dan pada siapa sasaran produk itu di pasarkan.

Selanjutnya John A. Welsh dan Jerry F. White dalam Astamoen (2008: 90),menyebutkan bahwa profil wirausaha yaitu percaya diri, hal ini juga melekat pada wira usaha di Pekanbaru seperti yang terungkap dari wawancara yaitu epercayaan yang masih dipakai hingga saat ini oleh pemilik usaha ini adalah jauhi riba untuk kesuksesan yang berkah, dan jangan pernah ragu untuk memulai usaha yakin dan percaya untuk memulai usaha serta membuat suatu usaha itu jangn ragu ragu cepat berusaha dan jangan takut gagal". Semua itu dilakukan dengan tekun, harus mengambil resiko dalam berusaha, berdoa, harus pandai mengelola usaha, kemauan terus belajar. Usaha terkadang memang naik turun persaingan usaha dimana mana, namun percaya rezeki pasti dating dan tidak tertukar, dan tetap semangat menjalankan usaha yang sedang kita jalani. 
Ciri lain yang disebutkan John A. Welsh dan Jerry F. White dalam Astamoen (2008: 90), adalah tidak pernah berhenti beraktifitas. Dalam wawancara banyak terungkap bahwa teruslah belajar kreatif dan jangan mudah menyerah. Perhatikan apa yang lagi hits sekarang, persiapkanlah, jangan lah terlalu banyak mikir, mulai saja dulu mumpung masih muda, habiskanlah jatah gagal kalian, nikmatilah suksenya. Ketika ingin melakukan usaha yaitu niat dalam berusaha, dan jika mengalami kegagalan dalam usaha jangan langsung menyerah. "Jangan pernah takut untuk mengambil keputusan dan harus yakin untuk menjalaninya karena suatu proses tidak pernah mengkhianati hasil"

\section{KESIMPULAN}

Tingkat pendidikan berkorelasi dengan omzet dan jumlah karyawan hal ini ditunjukan dengan perolehan nilai Sign $<0,05$, sedangkan jenis usaha, tingkat pendidikakan tidak berkorelasi dengan laba, jenis kelamin dan lama usaha karena perolehan nilai Sign $>0,05$.

Laba berkorelasi secara signifikan dengan omzet dan lama usaha, hal ini ditunjukan dengan nilain Sig yang diperoleh < 0,05. Sedangkan laba tidak berhungan dengan jenis usaha, tingkat pendidikan, jenis kelamin dan jumlah karyawan hal ini terlihat dari nilai Sig yang diperoleh $>0,05$.

Jenis usaha berkorelasi positif dengan omzet, jenis kelamin dan jumlah karyawan hal ini terlihat dari perolehan sign $<0,05$, sedangkan jenis usaaha tidak ada hubungan dengan laba, tingkat pendidikan, lamanya usaha karena nilai sign $>0,05$.

\section{DAFTAR PUSTAKA}

Anggun Abriwinoto. 2015. Pengaruh Profil Wirausaha Siswa Kelas XI Program Keahlian Tekbik Pemesinan SMK Muhammdiyah Prambanan Ditinjau Dari Minat Berwirausaha Siswa dan Lingkungan Keluarga. Program Studi Pendidikan Teknik Mesin Fak. Teknik UNY Yogyakarta 2015.

Ending Irianti. 2011. Profil Wirausaha Wanita di Desa Mengkirau Kec. Merbau dalam Perspektif Islam. Fakultas Syariah dan Ilmu Hukum UIN Sultan Syarif Kasim Pekanbaru.

Putri Wulandini. 2019. Analisis faktorfaktor yang mepenga-ruhi minat berwirausaha mahasiswa Universitas Islam Riau. Jurnal Akuntabel - pISSN: 0216-7743 eISSN: 2528-1135.

Sukarni. 2017. The Influence of SelfEfficacy and Achievement Motivation on Entrepreneurial Aspiration: The Case Study of Students from Riau Province. Global Journal Al Taqhafah university Sultan Azlan Syah Malaysia 11 (1).

Sukarni. 2017. Pengaruh Keadaan Diri, Unsur Penyokong dan Faktor Demografi Terhadap Tekad Kewirausahaan Pelajar Pendidikan Tinggi di Propinsi Riau, Prosiding EJurnal Kopertis 


\section{X, Seminar Nasional}

Univ.Abdurrab/ 1.

Suryana. 2006. Kewirausahaan pedoman praktis: kiat dan proses menuju sukses. Jakarta: Salemba Empat. Edisi ke-3.

Sugiyono. 2014. Metode Penelitian Pendidikan (Pendekatan kuantitatif, kualitatif, dan RED). Bandung: Alfabeta.

Sugiyono. 2014. Metode Penelitian Manajemen. Bandung: Alfabeta.

Yeri Andriyanto dan Henuk. 2016. Hubungan Profil Jiwa Wirausaha Terhadap Minat Berwirausaha Siswa SMK NEGERI 2 Depok Sleman.

Zulkarnain. 2006. Kewirausahaan Strategi Pemberdayaan Usaha kecil Menengah danPenduduk Miskin. Yogyakarta: Mitra Gama Widya. Cet. Ke-1. 